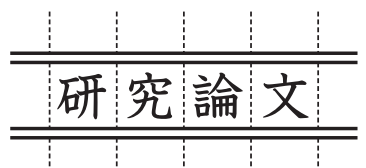

\title{
粒子分散複合材料のサイズ効果を考慮した曲げ強度計算手法 \\ Bending Strength Calculation Method of Particulate Composite with Size Effect
}

\author{
藤 原＼cjkstart誠*・請 井博 一* ・吉良 佳 子* \\ Makoto FUJIHARA, Hiroichi UKEI and Yoshiko KIRA
}

(Received October 20 2015)

\begin{abstract}
The mechanical strength of composite functional films is investigated by numerical simulation in this paper. Such functional film is often required bending strength during assembly. It is calculated composites with method to calculate equivalent macroscopic properties such as equivalent inclusion method and homogenization method, but these methods cannot be considered size effect. Therefore, we developed method to evaluate bending strength of particulate composite film by bending calculation of RVE with relative periodic condition. From the results of DOE bending calculations by the developed method, filler size shows a high contribution rate, however the size under 0.1 um doesn' $t$ affects the contribution rate.
\end{abstract}

Key Words: Particulate Composite, Bending Strength, Size Effect, FEM, RVE

\section{1. 緒 言}

機能性フィルムでは樹脂の中にフィラーを分散させた粒 子分散複合材料や発泡などにより樹脂内に空孔を生じさせ た多孔質材などにより多種の機能を付加する製品が多い。 この様な複合材料により巨視的に様々な機能、例えば、絶 縁性、断熱／放熱、低誘電性、大変形性（衝撃などの緩衝 材用途）などを付与することができる。しかし、これらの 機能性を向上できる反面、強度・剛性・回復性（弾性）な どの機械物性の低下が問題とされることがある。材料物性 の予測には材料を巨視的にみて均質材料とみなし、等価物 性を求める手法 ${ }^{1,2)}$ がよく利用されるが、これらの手法は 基本的にミクロモデル（フィラー・樹脂を別々とみなせる スケールでのモデル）は求める複合材料のスケールに対し 非常に小さいという仮定を元に、一様な変位場に対する強 度、弾性を議論している。そのため、フィラーサイズの影 響が計算されない。しかし、曲げ剛性・強度は現実的にフィ ラーサイズの影響を無視できない場合がある。特に、フィ ルム状の製品ではフィラーサイズの影響を無視できず、曲 げ剛性・強度を必要とされる場合、これらの手法では材料 設計が不十分となる。そこで、本稿では代表体積要素 (RVE : Representative Volume Element) モデルでの曲げモード変形 計算による粒子分散複合材料の曲げ強度設計を検討した。

\section{RVE モデル作成ツール}

本稿では粒子分散複合材料の曲げ強度設計の際の多数条 件での計算を考慮し、RVEモデルを半自動的に作成する

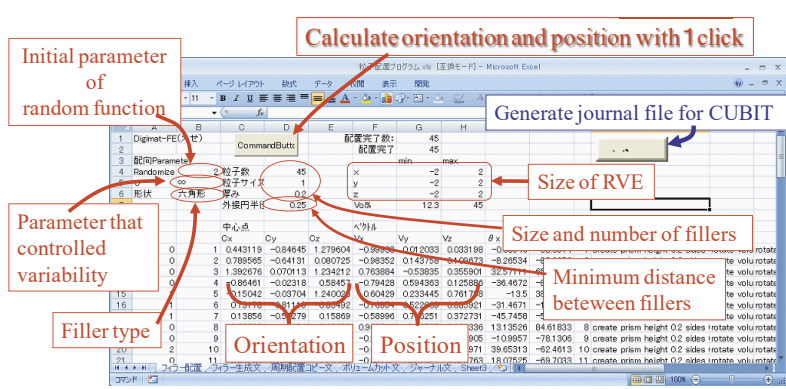

Fig.1 User interface of RVE modeling tool implemented on Excel

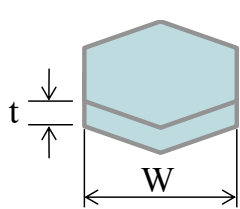

(a) Hexagonal prism

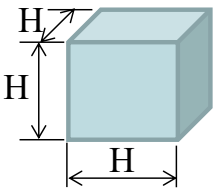

(b) Cube

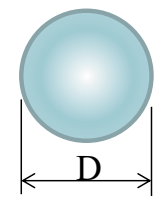

(c) Sphere
Fig.2 Schematic model of filler shapes and sizes

仕組みを構築することとした。メッシュ作成には CUBIT

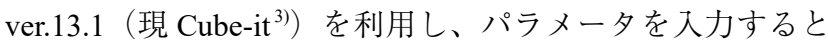
CUBIT 専用のジャーナルファイルを生成する Excel マクロ を作成した（Fig.1）。生成ジャーナルファイルを用いると CUBITにより自動的にRVE 形状が作成される。

本ッールにて考慮したパラメータは以下。

・フィラー形状（六角板、六角柱、球）（Fig.2）

*日東電工株式会社（ \%441-3194 愛知県豊橋市中原町字平山18 番地）

Nitto Denko Corporation (18 Hirayama, Nakahara, Toyohashi, Aichi, 441-3194 Japan) 
・フィラーサイズ (単分散)

・RVE モデルサイズ

・フィラー個数

・フィラー配向ばらつき

・フィラー間距離

フィラーは近傍のフィラーと干渉せず、かつ、指定され た距離を中心とする正規分布の確率で配置されるようにし た。フィラーのサイズ・個数と RVE 領域の比率を入力する ことにより含有率を制御可能とした。Fig.2に示すフィラー タイプの内、Fig.2(a)の六角板（柱）と Fig.2(b)の立方体 の配向は式 (1) の確率関数 ${ }^{4)}$ を用いて決定した。配向ばら つきは式 (1)、(2) 内の $\sigma$ の值を変更することにより制御可 能である。なお、位置や配向の決定にはランダム関数を利 用しており、初期值の変更により同条件で異なるモデルが 作成できるよう配慮した。

$$
\begin{aligned}
& f_{0}(\theta)=\frac{1}{C \sqrt{2} \sigma} \exp \left(-\frac{\theta^{2}}{2 \sigma^{2}}\right) \sin \theta \\
& C=\frac{1}{\sqrt{2} \sigma} \int_{0}^{\frac{\pi}{2}} \exp \left(-\frac{\theta^{2}}{2 \sigma^{2}}\right) \sin \theta d \theta
\end{aligned}
$$

また、RVE モデルを単位とした周期構造となる様にフィ

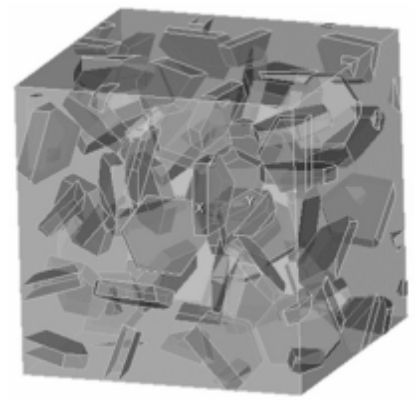

(a) Random

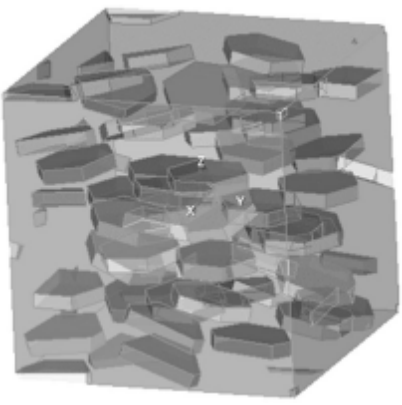

(b) +/-30 degree variation
Fig.3 Examples of solid model of RVE

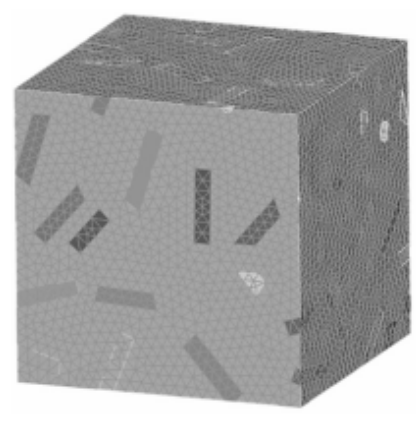

(a) RVE

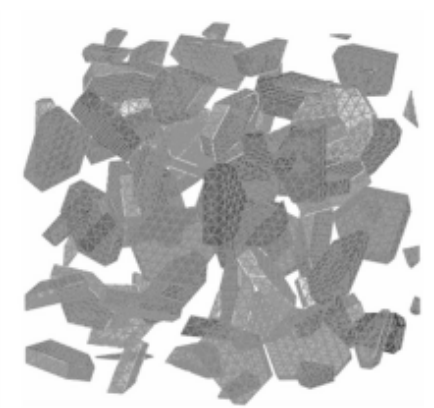

(b) Fillers in RVE
Fig.4 Tetrahedral mesh of RVE with random oriented fillers
ラーが配置される様にした。本ツールによる RVE モデルの 作成例として、Fig.3にランダム配向 $(\sigma \rightarrow \infty)$ と $\pm 30^{\circ}$ 配向 $(\sigma=\pi / 18)$ の場合の RVE モデルを示す。Fig.3に示す様な モデルを CUBIT で周期性を考慮しつつメッシュ作成するこ とにより Fig.4に示す様な RVE モデルのメッシュが作成で きる。

\section{3. サイズ効果を考慮した曲げ変形計算手法}

十分薄い単一材料のフィルムの曲げ弾性変形では Fig.5 の様に中立軸を境に引張／圧縮が反転するが、厚み方向に 線形にひずみが分布していると考えられる。

等価介在物法や均質化法などではフィラーは巨視構造 (フィルム全体の構造）より十分小さいと仮定することに より RVE モデルを Fig.5 の厚み方向の 1 点とみなすことが でき、変形は一様に加わっているとみなす。これはフィラー サイズが巨視構造と比較して十分に小さい場合には問題な い。しかし、フィルムの様な製品では巨視構造の代表寸法 である厚みも小さく、フィラーのサイズは巨視構造に対し て十分に小さいとは見なせない場合があり、前述の様な一 様変形場を仮定できるとは限らない。Fig.6にサイズの違 う構造に曲げ変形を加える場合の模式図を示す。図中では フィルムの曲げ模式図の上に複合材料の RVEを 1 つだけ重 ねている。Fig.5で示した様な曲げ変形の場合、異なるサ

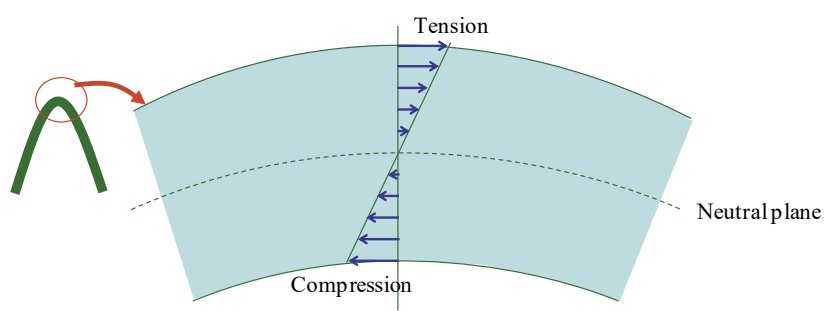

Fig.5 Schematic strain distribution during bending deformation

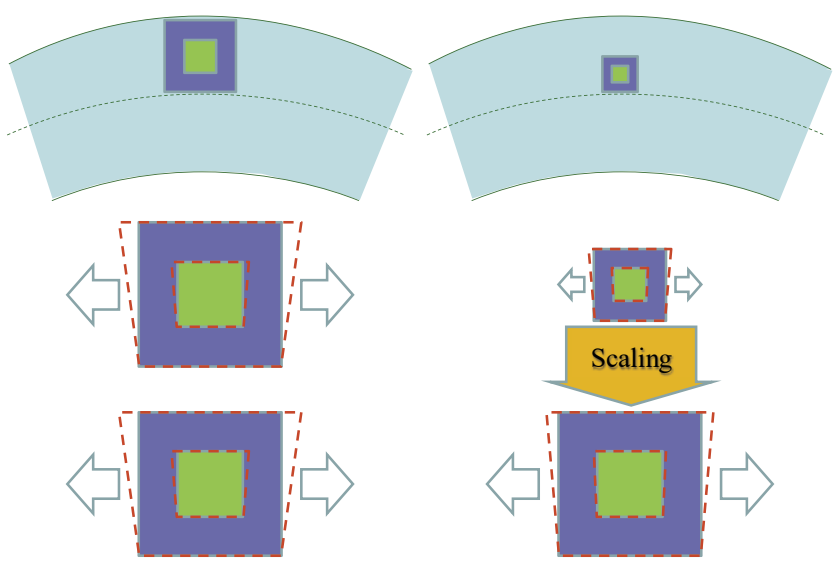

Fig.6 Schematic deformation with size effect 
スマートプロセス学会誌

イズの2つのRVEの下辺を中立軸の位置に揃えたとすると、 両者とも下辺のひずみは 0 となるが、RVEの上辺に与えら れるひずみはRVEのサイズが半分ではひずみも半分とな る。これら 2 つ RVEをサイズが紙面上で同じになる様に 拡大表示すると、Fig.6の最下段に示す様になり、両者の間 に破線で示した様な変形の相違が生ずる。このため、サイ ズの異なる相似形のフィラー／樹脂構造 (ミクロ構造) で あっても発生する応力分布が異なり、巨視的な曲げ強度は フィラーサイズによって変化することとなる。等価介在物 法や均質化法などの計算法では Fig.6 中の RVEの上辺と下 辺のひずみの差は無視されるために曲げ強度へのフィラー サイズの影響が計算できず、フィルムの曲げ強度設計には 不十分と考える。そこで、本稿では RVE モデルの曲げ変形 計算を利用する方法について考える。

Fig.5の様なひずみ分布になるのは線形弾性範囲内であ り、塑性変形や微小破壊が生ずる現象では成り立たたない。 RVE モデル単位で考えるとこのような非線形現象は隣接 RVEの影響を加味せねばならず、非常に計算負荷が大きい。 そこで、本稿では非線形領域でも Fig.5 の様な変形となる 一定曲率の曲げ変形を仮定した。この仮定のため定量的に は不充分だが、材料設計における定性的な判断は可能とな る。

RVE は周期性を仮定したモデルであり、その境界には式 (3) の様な周期境界条件が適用される。

$$
\boldsymbol{u}_{t}=\boldsymbol{u}_{r}
$$

$\boldsymbol{u}_{t}$ は境界上の変位であり、 $\boldsymbol{u}_{r}$ は周期的に対応する境界上の 変位である。式 (3) の周期境界条件では変位が周期的とな るために伸びや圧縮といった変形が拘束される。これを回 避するために周期的に対応する境界面の変形を相対的に拘 束することにより、境界面間の位置関係に自由度を持たせ る手法がある 5)。この手法では Fig.7に示す様に相対変位 $\Delta U$ を付加することにより周期境界面間の伸びや圧縮など の変形を許容する。逆に、この $\Delta U$ を規定することにより 巨視的な変形場を RVE モデルに与えることができる。

この手法を拡張し、Fig.8に示す様に一様曲率での曲げ 変形が加わったとし、周期境界条件式を定式化することと した。Fig.8では変形前の RVE モデルを実線四角、その周 囲の RVE モデルを点線四角で表現している。このような周 期的に並んだ RVE モデルに一様曲率での曲げ変形が加わっ たとすると、薄墨実線および破線の様な扇形に変形すると 考えられる。このように考えると、変形後は紙面横方向に は周期構造となるが、紙面上下方向には相似形を許容した 周期構造となる。

定式化に際し、更新ラグランジュ法による非線形計算へ の拡張を考慮した。またRVEモデルでの曲率を一様と仮定 しているので、曲げ変形の進行は曲率半径の変化で表現で きる。しかし、曲率半径を直接制御する場合、Fig.9(b)の
第 5 巻 第 1 号（2016 年 1 月）

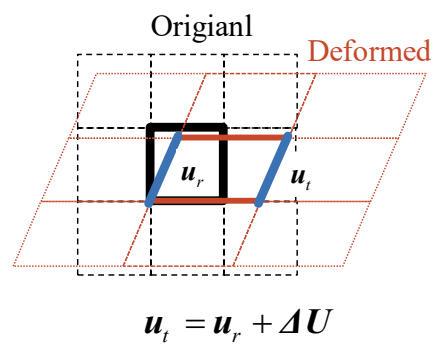

Fig.7 Relative periodic boundary condition

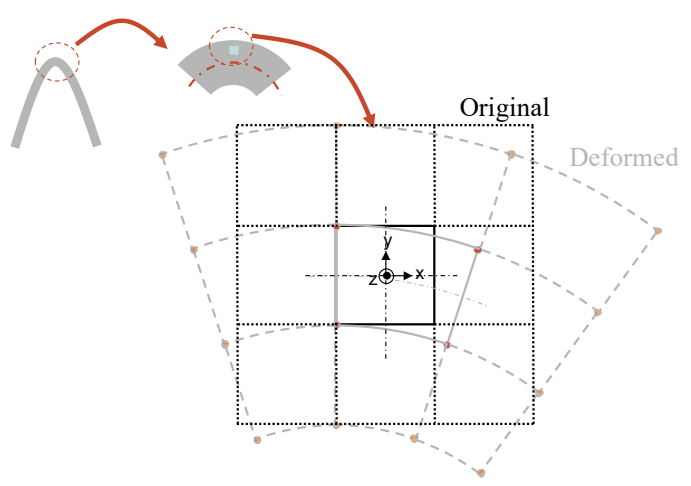

Fig.8 Schematic bending deformation of periodic RVE

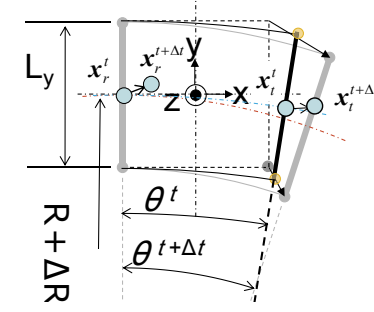

(a) Schematic deformation

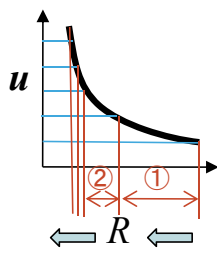

(b) Radius control

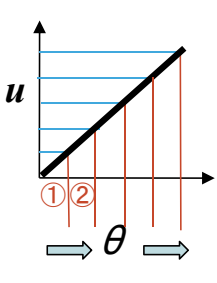

(c) Angle control
Fig.9 Two types of bending deformation control for RVE model

様に曲率半径に対する変形が非線形となり制御が困難とな る。そこで、Fig.9(a)に示す様な曲げ変形によるRVEの対 となる境界面のなす角度を制御することとした。これによ り、Fig.9(c)に示す様に角度に対する変形が線形となり制 御が容易となる。なお、Fig.9 中では変形後の境界面も直 線で表現しているが、実際には直線とは限らず、境界面の 変形も許容される。

RVE モデルは曲げを与える巨視構造のフィルムの中立軸 から Fig.10の様に $\Delta \mathrm{R}$ 離れた箇所の構造を抜き出したと仮 定すると、中立軸の曲率半径 R と RVE モデルの対となる 境界面のなす角度 $\theta^{t}$ との間には次式の関係がある。

$$
\theta^{t}=\frac{L}{R^{t}+\Delta R}
$$




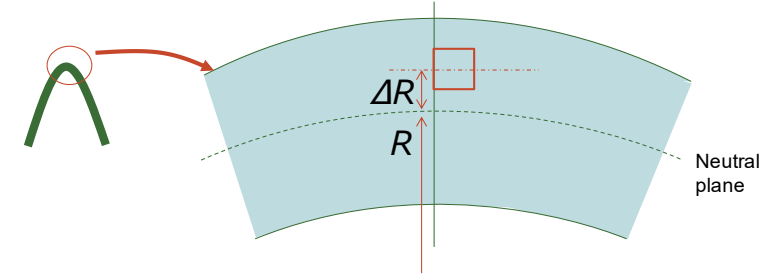

Fig.10 Position of RVE in bending film

\section{ただし、LはRVEの一辺の長さである。}

以上を前提として定式化を考える。まずは周方向周期境 界条件、すなわち Fig.9(a)の対となる太線の境界について 考える。周方向は変形後も周期構造だが、境界面が曲げに より $\theta^{t}$ 回転している。このため、対となる境界面上変位 の直交座標成分に直接周期境界条件を与えることはできな い。また、円筒座標成分に周期境界条件を与える事を考え た場合、時間ステップの進行とともに座標系原点が変わる ために、一つの円筒座標系では記述できない。そこで、時々 刻々と変化する円筒座標系上の座標成分を一つの固定され た直交座標系上に変換して考えることとする。ある時間ス テップ $t$ の計算が終了し、座標 $x^{t}$ が確定しており、次の時 間ステップ $t+\Delta t$ での座標 $x^{t+\Delta t}$ を計算することを考える。 簡便化のため RVE は Fig.9(a)で示す様に左辺の境界を $y z$ 平面平行面に固定（実際には境界面内での節点は個々に変 形し、対象の $y z$ 平面平行面内にはとどまらないが、全体的 に平均するとこの境界面は $y z$ 平面平行面に固定されている とみなす）して、右辺が変形するものと考える。時間ステッ プ $t+\Delta t$ における対となる境界面がなす角度は $\theta^{t+\Delta t}$ であり、

Fig.9(a) 右辺の境界面上の座標 $x^{t+\Delta t}$ は次式の様になる。

$$
\begin{aligned}
& \mathbf{x}_{t}^{t+\Delta t}+\left\{\begin{array}{c}
L_{x} / 2 \\
R^{t+\Delta t}+\Delta R \\
0
\end{array}\right\}=\mathbf{T}^{t} \cdot\left(\mathbf{x}_{r}^{t+\Delta t}+\left\{\begin{array}{c}
L_{x} / 2 \\
R^{t+\Delta t}+\Delta R \\
0
\end{array}\right\}\right) \\
& =\left[\begin{array}{crr}
\cos \theta^{t+\Delta t} & \sin \theta^{t+\Delta t} & 0 \\
-\sin \theta^{t+\Delta t} & \cos \theta^{t+\Delta t} & 0 \\
0 & 0 & 1
\end{array}\right]\left\{\left\{\begin{array}{c}
x_{r}^{t+\Delta t} \\
y_{r}^{t+\Delta t} \\
z_{r}^{t+\Delta t}
\end{array}\right\}+\left\{\begin{array}{c}
L_{x} / 2 \\
R^{t+\Delta t}+\Delta R \\
0
\end{array}\right\}\right)
\end{aligned}
$$

ただし、右下添え字の $t, r$ はそれぞれFig.9(a)の右辺の境 界上、左辺の境界上の值であることを示している。時間ス テップ $t+\Delta t$ での Fig.9(a) 右辺の境界面上の座標 $x_{t}^{t+\Delta t}$ は未 知数なので、時間ステップ $t$ の右辺境界面上の座標 $x_{t}^{t}$ と変 位で表現すると次式の様になる。

$$
\begin{aligned}
& \left\{\begin{array}{l}
x_{t}^{t} \\
y_{t}^{t} \\
z_{t}^{t}
\end{array}\right\}+\left\{\begin{array}{c}
u_{t}^{t+\Delta t} \\
v_{t}^{t+\Delta t} \\
w_{t}^{t+\Delta t}
\end{array}\right\}+\left\{\begin{array}{c}
L_{x} / 2 \\
R^{t+\Delta t}+\Delta R \\
0
\end{array}\right\}
\end{aligned}
$$

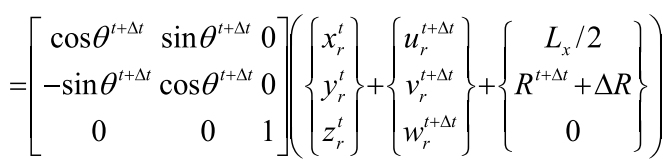

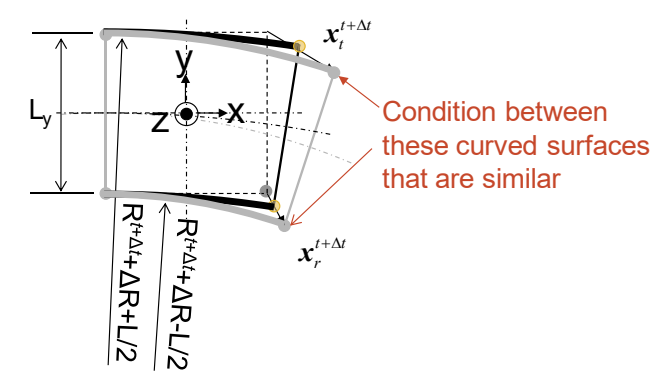

Fig.11 Schematic deformation of relative periodic condition

$u 、 v 、 w$ はそれぞれ変位の $x 、 y 、 z$ 成分である。変位間の 条件式としてまとめると、最終的に周方向の条件式は次式 のようになる。

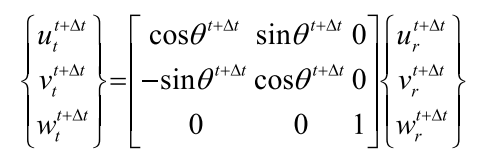

$$
\begin{aligned}
& +\left[\begin{array}{crr}
\cos \theta^{t+\Delta t} & \sin \theta^{t+\Delta t} & 0 \\
-\sin \theta^{t+\Delta t} & \cos \theta^{t+\Delta t} & 0 \\
0 & 0 & 1
\end{array}\right]\left(\left\{\begin{array}{c}
x_{r}^{t} \\
y_{r}^{t} \\
z_{r}^{t}
\end{array}\right\}+\left\{\begin{array}{c}
L_{x} / 2 \\
R^{t+\Delta t}+\Delta R \\
0
\end{array}\right\}\right)-\left\{\begin{array}{c}
x_{t}^{t} \\
y_{t}^{t} \\
z_{t}^{t}
\end{array}\right\}-\left\{\begin{array}{c}
L_{x} / 2 \\
R^{t+\Delta t}+\Delta R \\
0
\end{array}\right\}
\end{aligned}
$$

次にFig.11に示す径方向境界条件の定式化、すなわち Fig.11 中の下辺と上辺の境界面上の座標についての関係を 考える。径方向（紙面上下方向）の変形後の RVE は前述し た様に相似形になるものと仮定するので、Fig.11中の下辺 と上辺の境界面も相似形になるものと考えられる。ここで、 この両辺の相似比率は各境界面の曲率半径の比率に従い次 式のようになる。

$$
\alpha^{t+\Delta t}=\frac{R^{t+\Delta t}+\Delta R+L / 2}{R^{t+\Delta t}+\Delta R-L / 2}
$$

両境界面上での座標は次式の様な関係になる。

$$
\left\{\begin{array}{l}
x_{t}^{t} \\
y_{t}^{t} \\
z_{t}^{t}
\end{array}\right\}+\left\{\begin{array}{c}
u_{t}^{t+\Delta t} \\
v_{t}^{t+\Delta t} \\
w_{t}^{t+\Delta t}
\end{array}\right\}=\left[\begin{array}{ccc}
\alpha^{t+\Delta t} & 0 & 0 \\
0 & \alpha^{t+\Delta t} & 0 \\
0 & 0 & 1
\end{array}\right]\left\{\left\{\begin{array}{l}
x_{r}^{t} \\
y_{r}^{t} \\
z_{r}^{t}
\end{array}\right\}+\left\{\begin{array}{l}
u_{r}^{t+\Delta t} \\
v_{r}^{t+\Delta t} \\
w_{r}^{t+\Delta t}
\end{array}\right\}+\left\{\begin{array}{c}
L / 2 \\
L / 2 \\
0
\end{array}\right\}+\left\{\begin{array}{c}
-L / 2 \\
L / 2 \\
0
\end{array}\right\}(9)\right.
$$

式 (7) と同様に変位の関係式として、次式の様にまとめる。

$$
\begin{aligned}
& \left\{\begin{array}{c}
u_{t}^{t+\Delta t} \\
v_{t}^{t+\Delta t} \\
w_{t}^{t+\Delta t}
\end{array}\right\}=\left[\begin{array}{ccc}
\alpha^{t+\Delta t} & 0 & 0 \\
0 & \alpha^{t+\Delta t} & 0 \\
0 & 0 & 1
\end{array}\right]\left\{\begin{array}{c}
u_{r}^{t+\Delta t} \\
v_{r}^{t+\Delta t} \\
w_{r}^{t+\Delta t}
\end{array}\right\} \\
& \left.+\left[\begin{array}{ccc}
\alpha^{t+\Delta t} & 0 & 0 \\
0 & \alpha^{t+\Delta t} & 0 \\
0 & 0 & 1
\end{array}\right]\left\{\begin{array}{c}
x_{r}^{t} \\
y_{r}^{t} \\
z_{r}^{t}
\end{array}\right\}+\left\{\begin{array}{c}
L / 2 \\
L / 2 \\
0
\end{array}\right\}\right)+\left\{\begin{array}{c}
-L / 2 \\
L / 2 \\
0
\end{array}\right\}-\left\{\begin{array}{c}
x_{t}^{t} \\
y_{t}^{t} \\
z_{t}^{t}
\end{array}\right\}
\end{aligned}
$$

最後に $\mathrm{z}$ 軸方向（Fig.9(a)、Fig.11 上の紙面垂直方向）の条 件式は平面ひずみ状態を仮定し、次式に示す様に対となる 境界面で変位が同じ、一般的な周期境界条件を適用する。 


$$
\left\{\begin{array}{l}
u_{t}^{t+\Delta t} \\
v_{t}^{t+\Delta t} \\
w_{t}^{t+\Delta t}
\end{array}\right\}=\left\{\begin{array}{l}
u_{r}^{t+\Delta t} \\
v_{r}^{t+\Delta t} \\
w_{r}^{t+\Delta t}
\end{array}\right\}
$$

以上、式 (7)、(10)、(11) が曲げ変形のための相似周期境界 条件式となり、この条件式を対となる境界面上の対応する 節点対に対し適用すればよい。

変形の計算はエムエスシー・ソフトウェア(株)の商用構造 解析ソフトMarc2010.2 $2^{6)}$ を利用した。式 (7)、(10)、(11)の 適用には Marc の Link 機能とユーザーサブルーチン uformsn を利用した。Link 機能を適用する節点対の指定は手入力で も可能だが、複数条件での計算を考慮し、自動的に節点対 を探索し、式 (7)、(10)、(11)の式を適用したプリポストソ フトMentat 用の入力ファイルを出力するソフトを自社開発 した。

一般的に機能性フィルムでは剛性は主として要求され ず、ユーザーの製品への取り付け時の変形などでフィルム が破断せず、必要な機能が保たれるならば、微小破壊は許 容される。したがって、計算では樹脂の破壊を考慮した。 今回は Marc のユーザーサブルーチン uactive を利用し、し きい值を超えた要素の不活性化により破壊を表現すること とした。しきい值には相当ひずみを用いた。

\section{RVE 曲げ強度計算}

計算で利用した物性值を Table 1 に示す。

フィラーはセラミックスと考え、脆性材料とし、線形弾 性体で模擬した。樹脂は Fig.12に示すようにわずかに非線 形となるが、塑性領域が狭くすぐに破断するので亜弾性体 としてモデル化し、Table 1 に示すような関数で近似した。

Fig.12の実測データは一見滑らかにみえるが、実際には 微妙に值が上下に変動している。構造解析ソフトMarc の 非線形大变形計算では Newton 法を利用しており、この微 妙な上下変動により接線剛性が大きく変動し、計算の収束 性を悪化させる。その対策として表 1 に示すような単純 な近似関数でデータ点をなめらかに補正している。また、 Table 1 の近似関数は二次関数をべースとしているが、そ の二次関数の最大点は Fig.12に示す様に破断ひずみよりも 大きな点であり、計算上問題無いように考えられるが、実 際の収束計算中や収束後の要素不活性化判定時にこの最大 点を超えるひずみとなることがあり、計算を不安定にする。 そこで、破断ひずみ以上は線形に外挿したTable 1 の近似 関数を採用した。

まず、対象複合材料の一軸引張試験の実測と計算の比較 を行う。六角形様フィラー含有率 $12.3 \%$ ランダム配向の複 合材料であり、RVE モデルとメッシュはそれぞれ Fig.3(a)、 Fig.4 に示す。RVE モデルは 1 辺 $4 \mu \mathrm{m}$ の立方体であり、フィ ラーは Fig.2(a)の六角板で $\mathrm{W}=1 \mu \mathrm{m} 、 \mathrm{t}=0.2 \mu \mathrm{m}$ とした。 その結果を Fig.13 に示す。
Table 1 Material properties

\begin{tabular}{c||c}
\hline material & characteristic \\
\hline \hline Matrix resin & $\sigma=\left\{\begin{array}{cc}-7373 \varepsilon^{2}+1755 \varepsilon & (\varepsilon \leq 0.075) \\
649 \varepsilon+41 & (\varepsilon>0.075)\end{array}[\mathrm{MPa}]\right.$ \\
& Break point $: \varepsilon=0.075$ \\
\hline Filler & Elastic: $100 \mathrm{MPa}$ \\
\hline
\end{tabular}

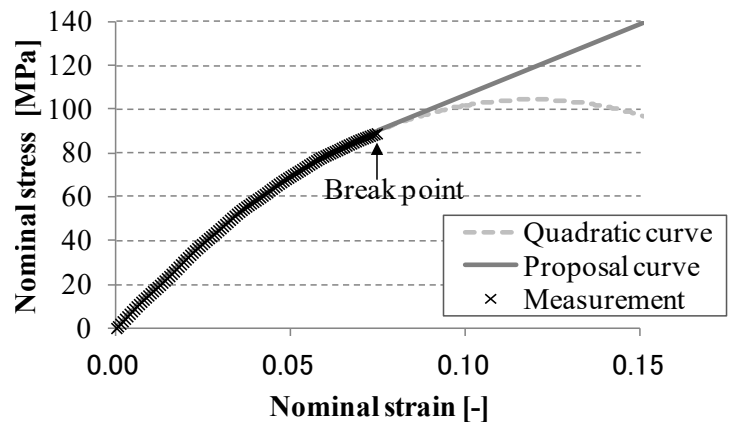

Fig.12 Tensile stress-strain diagram of matrix resin

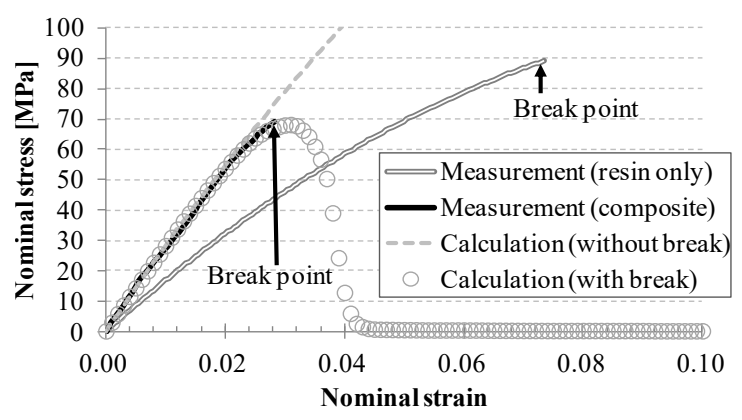

Fig.13 Comparison between measurement and calculation of tensile test

Fig.13では複合材料の実測結果は樹脂のみよりも傾きが 大きく、破断ひずみは約半分となっていることがわかる。 これに対しRVEモデルの計算結果はほぼ複合材料実測と同 様の傾きとなっているのがわかる。樹脂の微小な破壊を考 慮しない計算結果ではひずみ 0.02 あたりまでは実測とよい 一致を示すが、ひずみ 0.02 以上では実測の曲線はわずかに 傾きが小さくなり、破断に至る。微小破壊による全体剛性 の低下が生じているためである。これに対し、樹脂の微小 破壊を考慮した計算結果は実測の傾きの変化も追従できて おり、応力の最大点も実測の破断点に近く、よい一致を示 している。この結果により、計算モデルが妥当であること が確認できた。 
次に曲げ強度解析を実施した。結果を Fig.14に示す。対 象としたRVE モデルは Fig.14(a)に示しており、この RVE モデルの曲げ計算に前節で述べた式 (7)、(10)、(11)の境界 条件を適用する。この際、Fig.14(b) に示す様に曲げ構造物 の中立軸からの距離 $\Delta \mathrm{R}$ の位置がRVEモデルの中心と考え、 $\Delta \mathrm{R}$ の值を変えた条件での RVE モデルの曲げ計算を実施し、 破壊状況から定性的に評価した。計算に用いた RVEモデル のメッシュをFig.14(c)に示す。Fig.14(c) では樹脂を白色、 フィラーを薄墨色に色分けしている。 $\Delta \mathrm{R}$ の值を変えた計 算結果を Fig.14(d)〜 (i) に示す。コンターは相当ひずみを 示している。

Fig.14(d)、(e)に示す、それぞれ $\Delta \mathrm{R}=1 、 2 \mu \mathrm{m}$ の条件で はひずみが大きくなってきているが、RVE モデルへのき裂 は見られない。しかし、Fig.14(f)の $\Delta \mathrm{R}=3 \mu \mathrm{m}$ の条件では き裂が RVE モデルの中央あたりまで入っているのが確認で きる。RVEモデルの下辺あたりにも破壊が見られるがこれ は相似周期境界条件の適用により、上辺が破壊すると下辺 も破壊するためである。本来、下辺は破壊が生じないはず であり、厳密には正しくないが、破壊後の計算において上 辺の破壊は進展するが、下辺の破壊は進展しておらず、最 終的にFig.14(f)の様に上辺からき裂が入っている様子が 計算できており、ここでは下辺の破壊は無視するものとす る。Fig.14(g) に示す $\Delta \mathrm{R}=4 \mu \mathrm{m}$ ではき裂は RVEモデルを

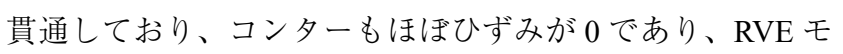
デルは破断したことがわかる。その後、Fig.14(h)、(i)に示 す $\Delta \mathrm{R} \geqq 5 \mu \mathrm{m}$ では破断した RVE モデルの左右の領域が離 れていることがわかる。Fig.14(d)〜 (i) のモデルはモデル サイズから考えても重なる領域があり、また破壊進展の観 点からも厳密には正しくないが、それぞれ Fig.14(b)の曲げ 構造物の中立軸からの $\Delta \mathrm{R}$ での RVE モデルと見なすことに より、き裂が曲げ構造物の上側から途中まで進展している 様子が計算できる。Fig.14の結果から、計算対象となる複 合材料ではき裂進展はほぼ $3 \mu \mathrm{m}$ と見なす。この様な評価 を異なる条件の複合材料で実施することにより、それぞれ の材料構成の定性的な比較を行う。

Fig.14の様なき裂進展計算では要素サイズの依存性があ るが、本稿の計算手法では破壊後の挙動はあまり重要では なく、かつ、周期構造の仮定から破壊の定量性を厳密には 議論できない。したがって、RVE 内部の微小き裂の進展に ついての精度はあまり議論せず、RVE 自体が破断する様な き裂の発生までを議論することとした。そこで、要素サイ ズは Fig.13の一軸引張試験の実験結果と齟䶜が生じない程 度で、かつ、本稿の計算手法は計算数が多くなるため、要 素数が必要以上に多くならない程度として、Fig.14(c)のサ イズとした。また、異なるRVEモデルにおいても、RVE サイズに対して相対的にほほ同じサイズとなるように全て のモデルで統一し、条件による要素サイズの影響度を小さ くし、フィラー形状や曲げ曲率の差による影響が反映され

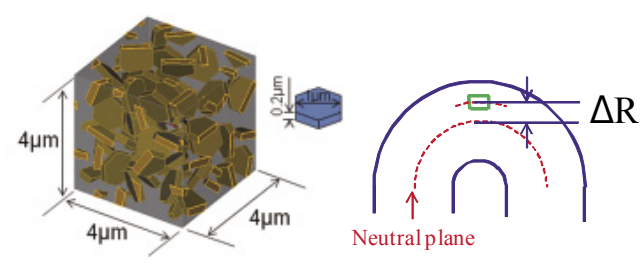

(a) RVE model

(b) Position of RVE

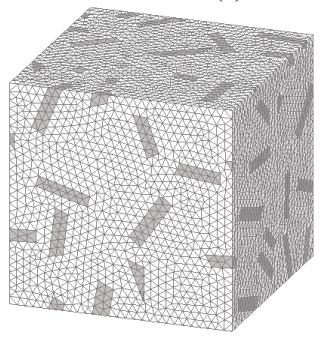

(c) Mesh of RVE

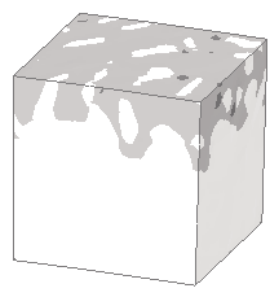

(d) $\Delta \mathrm{R}=1 \mu \mathrm{m}$

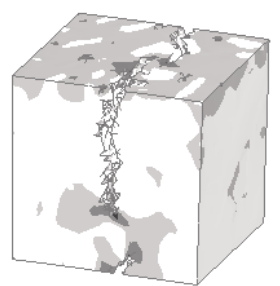

(f) $\Delta \mathrm{R}=3 \mu \mathrm{m}$

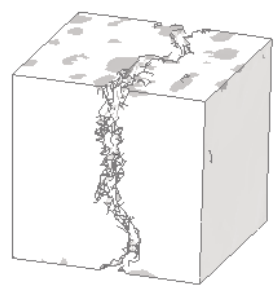

(h) $\Delta \mathrm{R}=5 \mu \mathrm{m}$

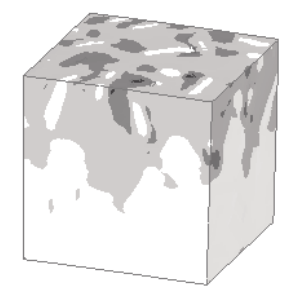

(e) $\Delta \mathrm{R}=2 \mu \mathrm{m}$

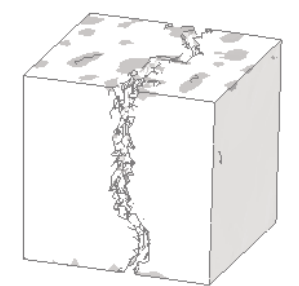

(g) $\Delta \mathrm{R}=4 \mu \mathrm{m}$

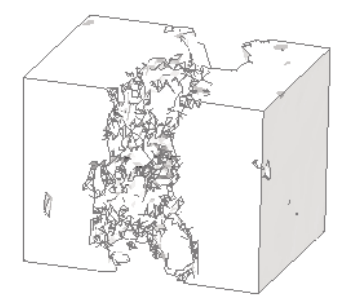

(i) $\Delta \mathrm{R}=40 \mu \mathrm{m}$
Fig.14 Bending strength calculation of RVE

るようにした。

以上のような曲げ強度評価手法を用い、フィラー含有率 とサイズの異なる条件でのフィラーサイズや形状による強 度の違いを計算した。その計算条件を Table 2 に示す。

フィラーはFig.15に示す 2 種類の形状を模擬し、 Fig.2(a)の六角板（柱）でモデル化した。サイズのみ異な る条件ではRVEモデル全体のサイズを変更した。そのため、 
Table 2 Parameters of RVE for bending strength evaluation

\begin{tabular}{|c|c|c|c|c|}
\hline \multirow{2}{*}{ No. } & \multicolumn{2}{|c|}{ Size of filler [ $[\mu \mathrm{m}]$} & \multirow{2}{*}{$\begin{array}{c}\text { Filler } \\
\text { content rate }\end{array}$} & \multirow{2}{*}{$\begin{array}{c}\text { Size of RVE L } \\
\text { [ } \mu \mathrm{m}]\end{array}$} \\
\hline & $W$ & $t$ & & \\
\hline 1 & 1.0 & 0.2 & \multirow{4}{*}{ 12.3Vol\% } & 4.0 \\
\hline 2 & 1.0 & 1.0 & & 4.0 \\
\hline 3 & 0.1 & 0.02 & & 0.4 \\
\hline 4 & 0.1 & 0.1 & & 0.4 \\
\hline 5 & 1.0 & 0.2 & \multirow{4}{*}{$5.9 \mathrm{Vol} \%$} & 4.0 \\
\hline 6 & 1.0 & 1.0 & & 6.0 \\
\hline 7 & 0.1 & 0.02 & & 0.4 \\
\hline 8 & 0.1 & 0.1 & & 0.6 \\
\hline No.1, 3 & & & No. 5,7 & No.6, 8 \\
\hline
\end{tabular}

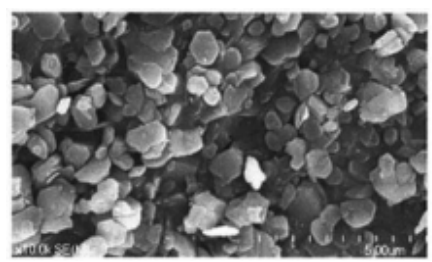

(a) Plate-like body

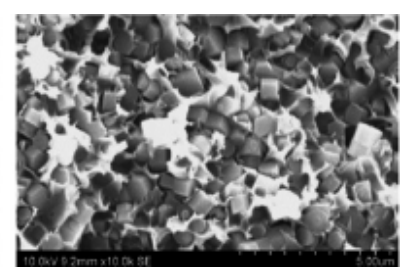

(b) Column-like body
Fig.15 Electron micrograph of two types of hexagonal prism filler

No.1 と 3、2 と 4、5 と 7、6 と 8 は寸法を無次元化すると Table 2 の下段に示す様に同じモデルとなる。なお、計算 では実寸法を考慮している。

以上の条件で計算を実施した。Table 2 の条件毎に $\Delta \mathrm{R}$ の異なる条件を複数計算し、き裂先端の位置を評価した。 その結果を Fig.16に示す。Fig.16 中には参考のため、対象 複合材料の樹脂単体の結果も示す。樹脂単体ならば、曲げ 構造のフルモデル計算も可能だが、同じ条件で評価するた めにRVEモデルと相似周期境界条件を用いたき裂先端位置 で評価した。

Fig.16より樹脂単体に比べ、複合材料のき裂先端位置は 半分以下となっており、Fig.13の一軸引張試験と同様の結 果となっている。これはフィラー近傍の樹脂が大きくひず み、微小破壊を生じ、それを起点にき裂が発生しやすくなっ ているためと考えられる。フィラー形状については以下の ことが言える。

・フィラー量が少ない方が強度大

・フィラーサイズが小さいほうが強度大

・フィラー形状は扁平でない方が強度大

これらの結果は一軸引張試験結果 (Fig.17) と傾向が一

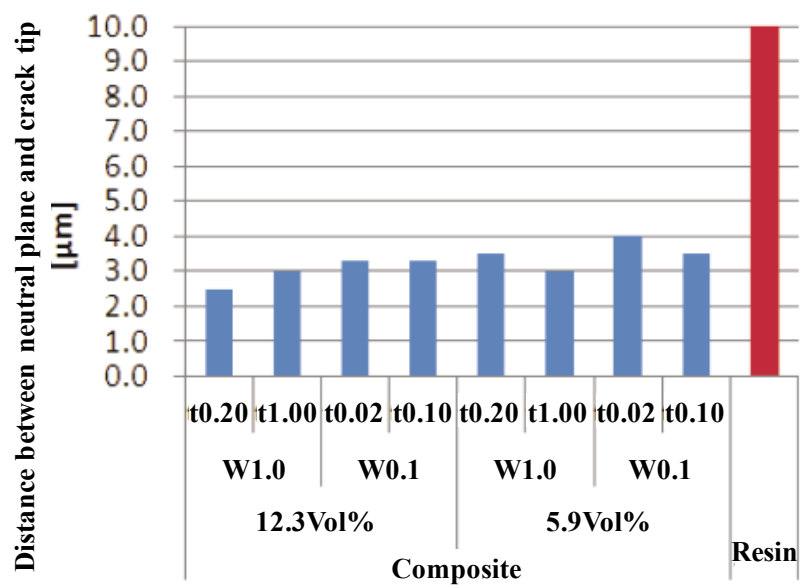

Fig.16 Results of bending strength evaluation

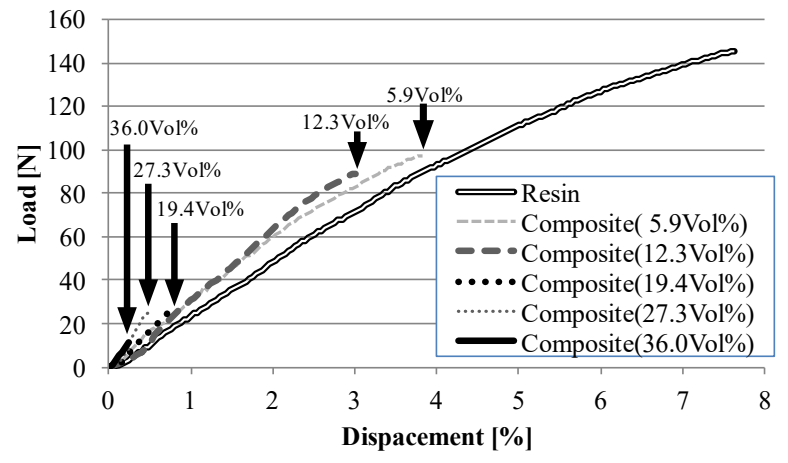

(a) Influence of consistent rate

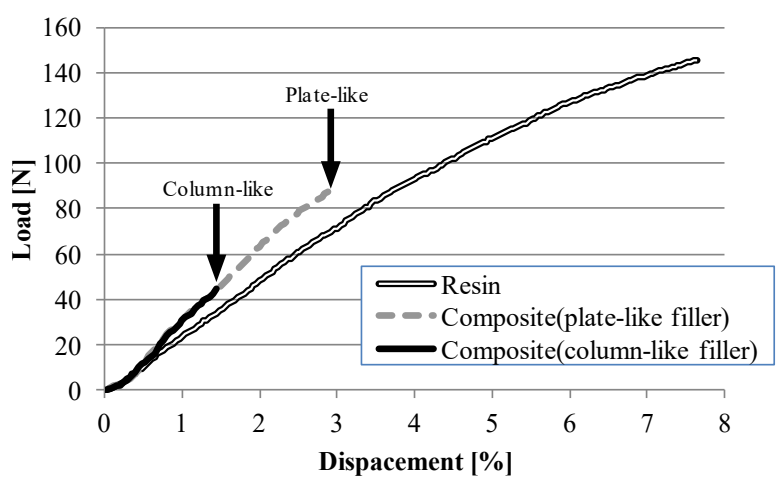

(b) Influence of filler type

Fig.17 Results of uniaxial tensile experiment

致しており、本校で提案する RVE モデルの曲げ計算を利用 した強度評価手法により各条件の優位差が判断できものと 考える。

\section{5. 実験計画法を用いた複合材料パラメータの影響調査}

前節で記述した様な RVE 曲げ強度評価手法を用い、製品 開発の方向性を明確にするために、実験計画法を用いて各 
Table 3 Orthogonal array table of DOE

\begin{tabular}{|c|c|c|c|c|c|c|c|c|c|c|c|}
\hline \multicolumn{3}{|c|}{\begin{tabular}{|ll} 
Factor & No. \\
\end{tabular}} & 1 & 2 & 3 & 4 & 5 & 6 & 7 & 8 & 9 \\
\hline \multicolumn{3}{|c|}{$1 \quad \begin{array}{l}\text { Consistent rate } \\
{[\mathrm{Vol} \%]}\end{array}$} & 2.9 & 2.9 & 2.9 & 5.9 & 5.9 & 5.9 & 12.3 & 12.3 & 12.3 \\
\hline \multicolumn{3}{|c|}{\begin{tabular}{l|l}
2 & Type \\
\end{tabular}} & Prism & Cube & Sphere & Prism & Cube & Sphere & Prism & Cube & Sphere \\
\hline \multirow{3}{*}{\multicolumn{2}{|c|}{$\mathrm{Siz}$}} & $\begin{array}{l}\text { Value } \\
{[\mu \mathrm{m}]}\end{array}$ & 0.05 & 0.1 & 1 & 0.1 & 1 & 0.05 & 1 & 0.05 & 0.1 \\
\hline & & $\begin{array}{l}\text { Lof RVE } \\
{[\mu \mathrm{m}]}\end{array}$ & 0.2 & 0.6 & 6.0 & 0.4 & 6.0 & 0.2 & 4.0 & 0.2 & 0.4 \\
\hline & & $\begin{array}{l}\text { Filler } \\
\text { image }\end{array}$ & & …1. & $\stackrel{1}{\longrightarrow}$ & $\stackrel{0.1}{\longrightarrow}$ & $\underset{k}{\pi}$ & 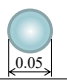 & & 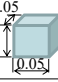 & $C_{0.1}$ \\
\hline \multicolumn{3}{|c|}{4 Dispersibility } & Low & Middle & High & High & Low & Middle & Middle & High & Low \\
\hline
\end{tabular}

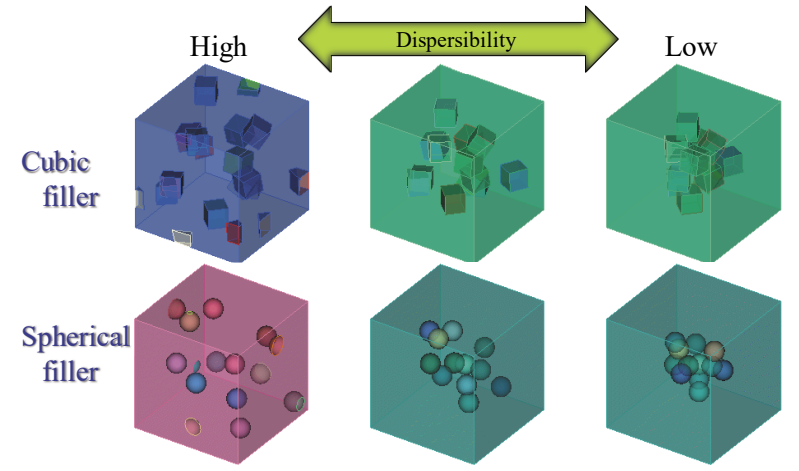

Fig.18 Dispersibility of RVE

種パラメータの影響度を調査した。選択したパラメータは 含有率、形状、サイズ、分散性である。含有率とサイズは それぞれ、2.9、5.9、12.3 Vol\% と 0.05、0.1、1 $\mu \mathrm{m}$ と水準 をふり、形状はFig.2に示した六角板、立方体、球とした。 Table 3 に実験計画法の直交表を示す。それぞれの RVEモ デルはモデル中のフィラー数が極端に少なくならない程度 の領域を確保することとし、表中のサイズとした。分散性 は開発したモデリングッールだけでは制御できないので、 次の様に手動で補正した。フィラー間距離により、ある程 度ベースのモデルを作成し、分散性、中、小のモデルは RVE モデルの中心にフィラーを寄せることにより分散性を 制御することとした。立方体フィラーと球状フィラーの分 散性を考慮したRVE モデルを Fig.18に示す。

分散性の高いモデルはモデリングッールで自動作成し た。分散性を制御する際に、フィラー形状、含有率などで 可能な限り同じ条件とするために Fig.19に示す様に周期的 に配列している事を考慮しつつ、RVE モデルの中心からの 距離に対するフィラーの存在頻度分布を合わせこむことと した。ただし、中心からの距離に対する頻度分布は距離が 離れるほど対象領域の増加に伴い頻度も増加するので、頻 度分布は単位体積当りとなるように補正した。

Table 3 の直交表の条件で前述の強度評価を実施した。 その結果を Fig.20に示す。

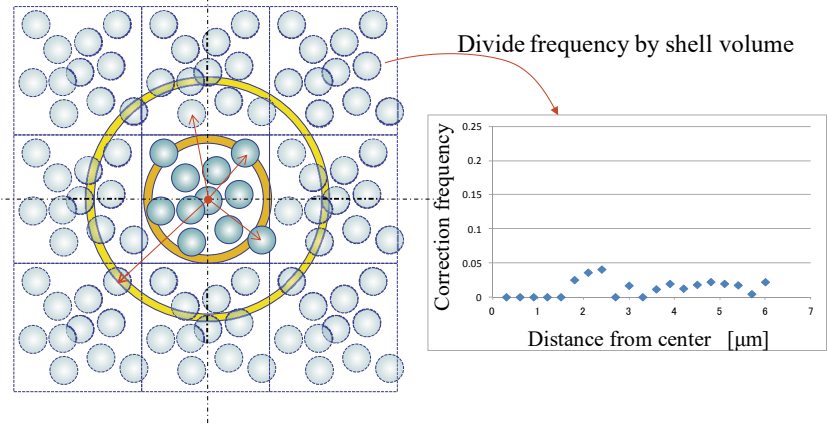

Fig.19 Correction frequency distribution

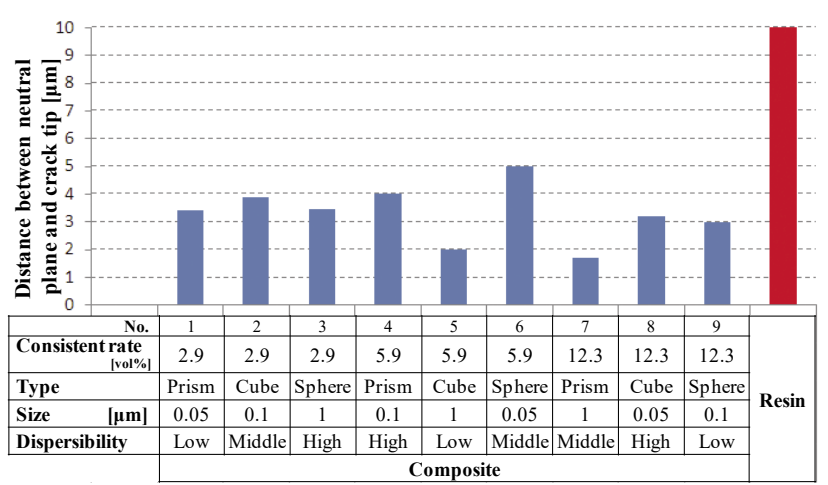

Fig.20 Results of strength evaluation of DOE

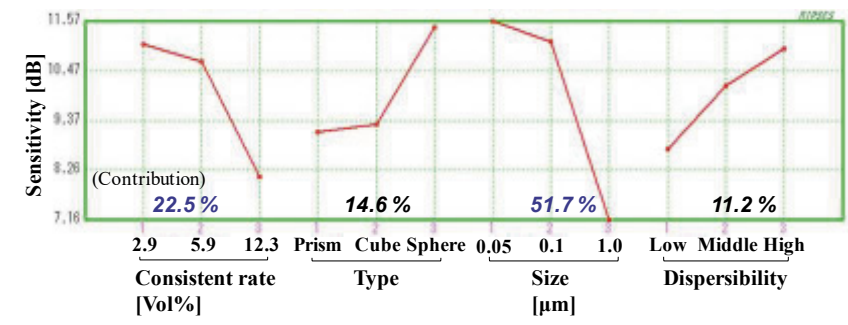

Fig.21 Factor effect plot (sensitivity)

Fig.20の強度評価結果から要因効果図を作成した。感度 グラフをFig.21に示す。なお、Fig.21 中には各因子の寄与 率も併記する。

Fig.21より、含有率は低いほど良く、形状は六角板 $<$ 立 方体く球形の順でよく、サイズは小さいほど良い。分散性 は高い方が良い。しかし、感度と寄与率から、以下のこと が言える。

(1) サイズは寄与率が最も高く、0.1 $\mu \mathrm{m}$ 以下で良い

(2) 含有率は $5.9 \mathrm{vol} \%$ 以下が良い

(3) 形状は球形が良いが寄与率は低い

(4) 分散性は高い方が良いが寄与率は低い

サイズが最も影響するが、0.1 $\mu \mathrm{m}$ 以下ならば差は小さく 
なり、形状（フィラータイプ）は球形の方が良いが影響度 が低い。また、製造工程に起因する分散性は高い方が良い が、その影響度は低いことがわかった。

\section{6. 結 言}

本稿では粒子分散複合材料からなる機能性フィルムの曲 げ強度評価手法を開発し、製品開発の方向性を示すために 実験計画法を用い、要因効果分析を行った。

複合材料の各種パラメータから RVE モデルを自動生成す るモデリングツールを開発し、周期構造を考慮した曲げ変 形のための相似周期境界条件式を定式化した。その周期条 件式を商用構造解析ソフトMarcに組込み、要素不活性化 による破壊を考慮したRVEの曲げ計算を実施した。フィル ム曲げ構造中立軸からの厚み方向位置を抜き出したRVEモ デルの曲げ強度計算による評価手法を提案した。

製品パラメータとして、フィラーの含有率、形状、サイズ、 分散性を因子とした実験計画法の計算により、製品開発の 方向性として、以下のことを示した。

1) サイズの寄与率は最も高く、0.1 $\mu \mathrm{m}$ 以下ならば良い。

2) 含有率は低い方が良いが、 $5.9 \mathrm{Vol} \%$ 以下は効果が低い

3) 形状は球形が最も良いが、寄与率は低い

4) 分散性は寄与率が予想に反し低い。

本稿の強度評価では複合材料の重要な課題の一つである 材料界面強度を考慮していない。これは材料界面強度の定 量值を実測で評価できていないためであり、ある程度の精 度の実測データがあれば考慮することは可能である。また、 一連の計算手法は、等価介在物法や均質化法などの複合材 料の数值計算手法では困難なフィラーサイズの影響を考慮 した曲げ強度解析手法だが、定性的な評価のみであり、複
数種の複合材料を組合せた製品の評価はできない。この様 な製品設計に適用するためにはサイズ効果を考慮した定量 的な曲げ強度計算手法が必要となる。曲げ強度では曲げ剛 性がフィラーサイズの影響を受けるので、例えば、曲げ剛 性自体を巨視物性化した二次均質化法 ${ }^{7)}$ などの計算手法に 期待する。

\section{謝 辞}

マイクロマグネティックス計算手法と共に配向モデリン グ手法をご教示いただいた長崎大学 福永博俊 教授に感 謝の意を表します。

\section{参考文献}

1) Toshio Mura, "Micromechanics of Defects in Solids", Second, Revised Edition Kluwer Academic Publishers, 1987.

2) 寺田賢二郎 ·菊池昇、日本計算工学会編、“均質化法入門”、 丸善 (2003).

3) http://www.cube-it.jp/

4) 福永博敏、桐生一生、中野正基、柳井武志、“Nd-Fe-B 磁石の 磁化反転過程に及ぼす静磁気相互作用の影響一計算機シミュ レーションー”、日本金属学会、76-1 (2012) 43-47.

5) 座古勝、藤原誠、“面内周期性と幾何学的非線形性を考慮した 織物繊維強化複合材料の変形挙動解析手法”、繊維機械学会誌、 54-1 (2001) 45-52.

6) http://www.mscsoftware.com/ja

7) M. Uchida, N. Tada, "Computational simulation of micro- to macroscopic deformation behavior of cavitated rubber blended amorphous polymer using second-order homogenization method", Key Engineering Materials, 626 (2014) 74-80. 